\title{
Basic Consideration for Various Interfaces from Viewpoint of Service
}

\author{
A. Toshiki Yamaoka and Mayuko Yoshida \\ Wakayama University, Faculty of Systems Engineering, \\ Sakedani-930, Wakayama city, Japan \\ yamaoka@sys.wakayama-u.ac.jp
}

\begin{abstract}
Service business was classified into three categories. A design framework of user interface, especially screen design for the three categories of service was constructed roughly from viewpoint of theory of regulatory focus, transactional analysis (TA) and psychological impression. According to the three categories, three examples of screen design were designed roughly.
\end{abstract}

Keywords: Service, screen design, user interface, theory of regulatory focus, transactional analysis (TA), psychological impression.

\section{Introduction}

Service business in $21^{\text {st }}$ century becomes very important industry. However, relationship between service and user interface (screen design) has not been examined until now. Then, the paper describes a design framework of user interface, especially screen design for service from viewpoint of theory of regulatory focus, transactional analysis (TA) and psychological impression.

\section{Classification of Service}

61 business persons were asked regarding objects and services. They are as follows. Objects:

1. medical treatment

2. restaurant

3. self-restaurant

4. laundry

5. laundry(self service)

6. beauty salon

7. movie/drama

8. ATM

9. plane

10.reservation of plane ticket

11.home delivery service 


\section{2.hotel}

\section{3.amusement park}

14.game arcade

15.education

16.repair of home electrical appliance

17.net shopping

18.retrieval in bookstore

\section{Services:}

1. attitude of employee

2. good HMI (Human Machine Interface)

3. changed service based on customer

4. providing reliable service

5. providing effective service

6. expected service accepted

7. providing added service

8. staff cooperated with customer for service

9. low price

10.taking much time for service

11.enjoyable process of service

If object and service are related, subject checked. The data gotten from questionnaire were analyzed using correspondence analysis and cluster analysis.

Table 1. Relationship between objects and services (frequency / total)

\begin{tabular}{|l|l|l|l|l|l|l|l|l|l|l|l|}
\hline & $(1)$ & $(2)$ & $(3)$ & $(4)$ & $(5)$ & $(6)$ & $(7)$ & $(8)$ & $(9)$ & $(10)$ & $(11)$ \\
\hline medical treatment & 0.70 & 0.23 & 0.60 & 0.91 & 0.55 & 0.75 & 0.23 & 0.26 & 0.32 & 0.83 & 0.04 \\
\hline restaurant & 0.87 & 0.06 & 0.36 & 0.40 & 0.59 & 0.77 & 0.51 & 0.08 & 0.25 & 0.08 & 0.42 \\
\hline self-restaurant & 0.15 & 0.51 & 0.06 & 0.30 & 0.64 & 0.34 & 0.09 & 0.26 & 0.83 & 0.02 & 0.09 \\
\hline laundry & 0.38 & 0.05 & 0.12 & 0.57 & 0.52 & 0.67 & 0.19 & 0.14 & 0.45 & 0.19 & 0.00 \\
\hline laundry (self service) & 0.00 & 0.62 & 0.00 & 0.35 & 0.52 & 0.35 & 0.07 & 0.31 & 0.76 & 0.03 & 0.03 \\
\hline beauty salon & 0.09 & 0.02 & 0.68 & 0.71 & 0.32 & 0.78 & 0.51 & 0.12 & 0.22 & 0.59 & 0.44 \\
\hline movie/drama & 0.20 & 0.11 & 0.04 & 0.22 & 0.30 & 0.44 & 0.20 & 0.07 & 0.17 & 0.00 & 0.44 \\
\hline ATM & 0.20 & 0.75 & 0.10 & 0.72 & 0.73 & 0.49 & 0.04 & 0.31 & 0.00 & 0.18 & 0.00 \\
\hline Plane plane & 0.76 & 0.22 & 0.37 & 0.56 & 0.37 & 0.53 & 0.45 & 0.08 & 0.14 & 0.06 & 0.22 \\
\hline $\begin{array}{l}\text { reservation of } \\
\text { ticket }\end{array}$ & 0.19 & 0.61 & 0.13 & 0.61 & 0.74 & 0.45 & 0.03 & 0.39 & 0.00 & 0.03 & 0.00 \\
\hline home delivery service & 0.52 & 0.07 & 0.17 & 0.71 & 0.57 & 0.57 & 0.11 & 0.15 & 0.44 & 0.07 & 0.00 \\
\hline hotel & 0.97 & 0.10 & 0.53 & 0.65 & 0.41 & 0.73 & 0.80 & 0.06 & 0.16 & 0.12 & 0.43 \\
\hline amusement park & 0.44 & 0.33 & 0.19 & 0.26 & 0.43 & 0.43 & 0.41 & 0.26 & 0.19 & 0.05 & 0.64 \\
\hline game arcade & 0.13 & 0.44 & 0.08 & 0.22 & 0.25 & 0.28 & 0.19 & 0.31 & 0.42 & 0.03 & 0.44 \\
\hline education & 0.52 & 0.05 & 0.55 & 0.67 & 0.26 & 0.60 & 0.26 & 0.19 & 0.19 & 0.57 & 0.36 \\
\hline $\begin{array}{l}\text { repair of } \\
\text { electrical appliance }\end{array}$ & 0.61 & 0.06 & 0.26 & 0.68 & 0.52 & 0.61 & 0.13 & 0.06 & 0.39 & 0.26 & 0.00 \\
\hline net shopping & 0.11 & 0.63 & 0.13 & 0.66 & 0.66 & 0.47 & 0.34 & 0.24 & 0.63 & 0.05 & 0.21 \\
\hline \begin{tabular}{l} 
retrieval in bookstore \\
\hline
\end{tabular} & 0.10 & 0.67 & 0.08 & 0.23 & 0.69 & 0.49 & 0.05 & 0.39 & 0.00 & 0.00 & 0.10 \\
\hline
\end{tabular}




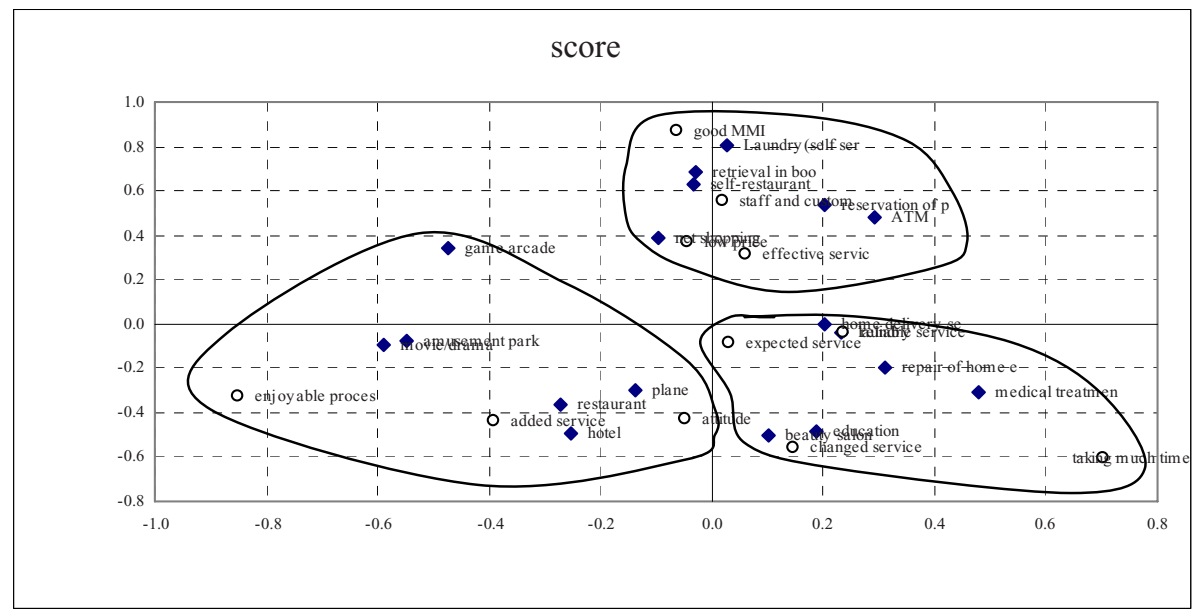

Fig. 1. Three classification of service

The questionnaire was analyzed using correspondence analysis and cluster analysis. The results are as follows.

1. "pleasure" service group

Objects: restaurant, movie/drama, plane, hotel, amusement park, game arcade

Services: providing added service, enjoyable process of service

2. "low cost and effective" service group

Objects: self-restaurant, laundry (self service), ATM, reservation of plane ticket, net shopping, retrieval in bookstore

Services: good HMI (Human Machine Interface), providing effective service, staff cooperated with customer for service, low price

3. "reliable and expected" service group

Objects: medical treatment, laundry, beauty salon, home delivery service, education, repair of home electrical appliance

Services: attitude of employee, changed service based on customer, providing reliable service, expected service accepted, taking much time for service

\section{Characteristics of Three Classification of Service}

The three classification of service was analyzed using transactional analysis (TA) theory of regulatory focus and psychological impression after using.

Theory of regulatory focus consists of promotion focus and prevention focus [1] [4]. The promotion focus means that every person works to maximize positive action results and minimize non-positive loss for promotion and self-realization. The prevention focus means that every person works to protect themselves against the 
occurrence of unpleasant states. So, user interface of product and service and so on can be designed and analyzed based on the viewpoint of promotion focus and prevention focus.

1. "pleasure" service group : promotion focus

2. "low cost and effective" service group: prevention focus

3. "reliable \& expected" service group: prevention focus

Table 2. characteristics of three classification of service

\begin{tabular}{|c|c|c|c|}
\hline group & $\begin{array}{c}(1) \\
\text { "pleasure" } \\
\text { service group }\end{array}$ & $\begin{array}{c}(2) \\
\text { "low cost and } \\
\text { effective" service } \\
\text { group }\end{array}$ & $\begin{array}{c}(3) \\
\text { "reliable \& expected" } \\
\text { service group }\end{array}$ \\
\hline \multirow[t]{2}{*}{$\begin{array}{c}\text { object / } \\
\text { user interface }\end{array}$} & $\begin{array}{c}\text { restaurant, } \\
\text { movie/drama, } \\
\text { plane, hotel, } \\
\text { amusement park, } \\
\text { game arcade }\end{array}$ & $\begin{array}{l}\text { self-restaurant, } \\
\text { laundry(self } \\
\text { service), ATM, } \\
\text { reservation of plane } \\
\text { ticket, } \\
\text { net shopping, } \\
\text { retrieval in } \\
\text { bookstore }\end{array}$ & $\begin{array}{l}\text { medical treatment, } \\
\text { laundry, } \\
\text { beauty salon, } \\
\text { home delivery } \\
\text { service, } \\
\text { education, } \\
\text { repair of home } \\
\text { electrical appliance }\end{array}$ \\
\hline & user interface & user interface & user interface \\
\hline $\begin{array}{c}\text { theory of } \\
\text { regulatory focus }\end{array}$ & promotion focus & prevention focus & prevention focus \\
\hline $\begin{array}{l}\text { transactional } \\
\text { analysis (TA) }\end{array}$ & $\begin{array}{l}\mathrm{A} \rightarrow \mathrm{A}(\text { adult }) \\
\mathrm{C} \rightarrow \mathrm{C}(\text { child }) \\
\mathrm{P}(\text { parent }) \rightarrow \mathrm{C}\end{array}$ & $\mathrm{A} \rightarrow \mathrm{A}$ & $\mathrm{A} \rightarrow \mathrm{A}$ \\
\hline $\begin{array}{l}\text { psychological } \\
\text { impression } \\
\text { after using }\end{array}$ & $\begin{array}{l}\text { feel pleasure } \\
\text { or impression }\end{array}$ & feel ease to use & $\begin{array}{l}\text { feel sense of security } \\
\text { or reliability }\end{array}$ \\
\hline
\end{tabular}

As TA [3] is a method to improve communication, relationship between human and machine (system) was analyzed using TA.

1. "pleasure" service group:

Device provides human with information based on three different communication patters of TA which is "adult to adult", "child to child" and "parent to child".

2. "low cost and effective" service group:

Device provides human with information based on "adult to adult" pattern of TA.

3. "reliable \& expected" service group

Device provides human with information based on "adult to adult" pattern of TA. 
Finally, the three classification of service are analyzed from viewpoint of psychological impression [2] after using.

1. "pleasure" service group : feel pleasure or impression

2. "low cost and effective" service group: feel ease to use

3. "reliable \& expected" service group: feel sense of security or reliability

The three classification of service were made clear using transactional analysis (TA) theory of regulatory focus and psychological impression after using.

\section{A Screen Design Example Corresponded to Three Classification of Service}

Specifications of screen design based on characteristics of three classification of service are shown in table3.

Table 3. a specification of screen design based on characteristics of three classification of service

\begin{tabular}{|c|c|c|c|}
\hline group & $\begin{array}{c}\text { (1) } \\
\text { "pleasure" } \\
\text { service group }\end{array}$ & $\begin{array}{c}(2) \\
\text { "low cost and } \\
\text { effective" service } \\
\text { group }\end{array}$ & $\begin{array}{c}(3) \\
\text { "reliable \& expected" } \\
\text { service group }\end{array}$ \\
\hline & user interface & user interface & user interface \\
\hline $\begin{array}{c}\text { theory of } \\
\text { regulatory focus }\end{array}$ & promotion focus & prevention focus & prevention focus \\
\hline $\begin{array}{l}\text { transactional } \\
\text { Analysis (TA) }\end{array}$ & $\begin{array}{l}\mathrm{A} \rightarrow \mathrm{A}(\text { adult }) \\
\mathrm{C} \rightarrow \mathrm{C}(\text { child }) \\
\mathrm{P}(\text { parent }) \rightarrow \mathrm{C}\end{array}$ & $\mathrm{A} \rightarrow \mathrm{A}$ & $\mathrm{A} \rightarrow \mathrm{A}$ \\
\hline $\begin{array}{l}\text { psychological } \\
\text { impression } \\
\text { after using }\end{array}$ & $\begin{array}{l}\text { feel pleasure } \\
\text { or impression }\end{array}$ & feel ease to use & $\begin{array}{c}\text { feel sense of security } \\
\text { or reliability }\end{array}$ \\
\hline title & needful & needful & needful \\
\hline explanation & $\begin{array}{r}\text { describe } \\
\text { decoratively }\end{array}$ & describe simply & describe in detail \\
\hline $\begin{array}{l}\text { parts (button, } \\
\text { etc) }\end{array}$ & $\begin{array}{l}\text { decorative, } \\
\text { no shade of } \\
\text { button }\end{array}$ & $\begin{array}{l}\text { simple, } \\
\text { need shade of } \\
\text { button }\end{array}$ & metaphor \\
\hline $\begin{array}{l}\text { confirmation } \\
\text { of operation }\end{array}$ & needless & $\begin{array}{l}\quad \text { needless } \\
\text { (automation) } \\
\text { (sometimes, } \\
\text { needful) }\end{array}$ & needful \\
\hline $\begin{array}{l}\text { concrete / } \\
\text { abstract }\end{array}$ & concrete & abstract & concrete \\
\hline
\end{tabular}


The following design ideas are created according to table 3.

1. "pleasure" service group :

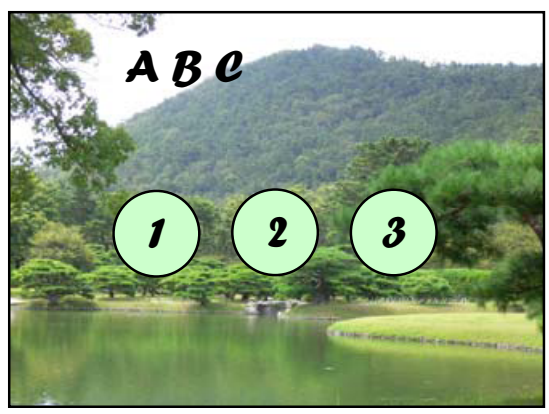

Theory of regulatory focus: promotion focus

Transactional Analysis (TA):

$$
\text { C C }
$$

Psychological impression:

feel pleasure

Design: concrete

2. "low cost and effective" service group:

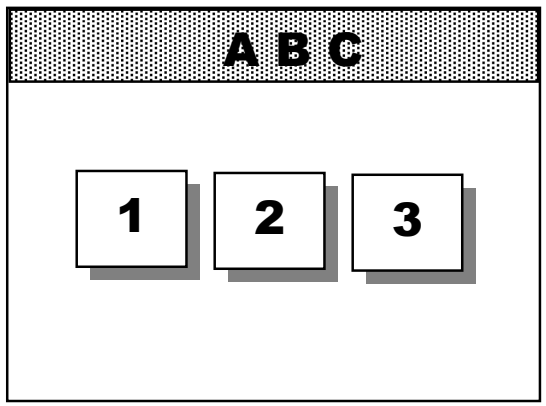

Theory of regulatory focus: prevention focus

Transactional Analysis (TA):

A A

Psychological impression:

feel ease to use

Design: abstract

The shade of button is needed.

3. "reliable \& expected" service group

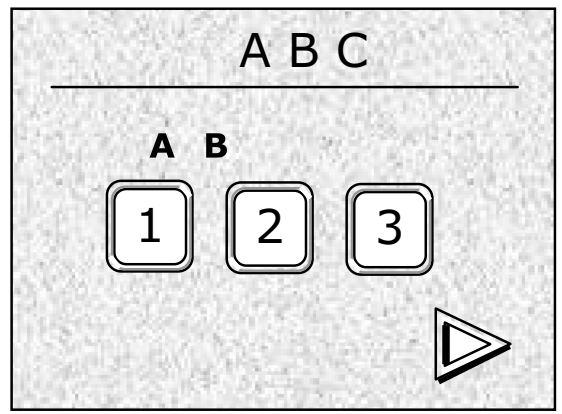

Theory of regulatory focus: prevention focus

Transactional Analysis (TA):

A A

Psychological impression:

feel sense of security

Design: concrete

The button is quoted from real button.

Confirmation of operation is needed.

\section{Discussion}

Framework of user interface, especially screen design based on service was made clear roughly. Although service was classified into three categories, the concept of 
service has to be identified. The layout, parts and so on of screen design was decided according to the identified concept. The design procedure is as follows.

1. Examine theory of regulatory focus.

Promotion focus or prevention focus is decided according to the theory of regulatory focus.

2. Decide type of communication between human and machine (system).

The combination of adult, child and parent is decided based on the promotion focus or prevention focus.

3. Psychological impression is decided.

The psychological impression after using a machine is decided according to TA.

\section{References}

1. Higgins, E.T.: Beyond pleasure and pain. American Psychologist 52, 1280-1300 (1997)

2. Kobayashi, Y., Katho, Y., Nishida, Y., Mizuno, Y., Yoshida, K., Yoshida, M., Yamaoka, T.: Consideration of product evaluation method focused on interaction between product and user. In: Proceedings of Knsai Chapter of Japan Ergonomics Society, pp. 5-8 (2006)

3. Okano, Y., Tada, T.: Start for new oneself - TA for management, syakai-sangyou-kyouikukenkyuujo (197)

4. Werth, L., Foerster, J.: How regulatory focus influence consumer behavior. European Journal of Social Psychology 36, 1-19 (2006) 